University of Nebraska - Lincoln

DigitalCommons@University of Nebraska - Lincoln

Nebraska Cooperative Fish \& Wildlife Research Nebraska Cooperative Fish \& Wildlife Research Unit -- Staff Publications

2009

\title{
Stomach Capacities of Six Freshwater Fishes
}

\author{
Nathan J.C. Gosch \\ University of Nebraska-Lincoln, Nathan.J.Gosch@usace.army.mil \\ Kevin L. Pope \\ University of Nebraska-Lincoln, kpope2@unl.edu \\ Paul H. Michaletz \\ Missouri Department of Conservation
}

Follow this and additional works at: https://digitalcommons.unl.edu/ncfwrustaff

Part of the Other Environmental Sciences Commons

Gosch, Nathan J.C.; Pope, Kevin L.; and Michaletz, Paul H., "Stomach Capacities of Six Freshwater Fishes" (2009). Nebraska Cooperative Fish \& Wildlife Research Unit -- Staff Publications. 44.

https://digitalcommons.unl.edu/ncfwrustaff/44

This Article is brought to you for free and open access by the Nebraska Cooperative Fish \& Wildlife Research Unit at DigitalCommons@University of Nebraska - Lincoln. It has been accepted for inclusion in Nebraska Cooperative Fish \& Wildlife Research Unit -- Staff Publications by an authorized administrator of DigitalCommons@University of Nebraska - Lincoln. 


\title{
Stomach Capacities of Six Freshwater Fishes
}

\author{
Nathan J.C. Gosch ${ }^{\mathrm{a}}$ and Kevin L. Pope \\ Nebraska Cooperative Fish and Wildife Research Unit \\ School of Natural Resources, University of Nebraska-Lincoln \\ Lincoln, Nebraska 68583 USA \\ and \\ Paul H. Michaletz \\ Missouri Department of Conservation \\ Columbia, Missouri 65201 USA
}

\begin{abstract}
We investigated the relationship between stomach capacity and total body length in bluegill (Lepomis macrochirus), spotted bass (Micropterus punctulatus), white crappie (Pomoxis annularis), black crappie (Pomoxis nigromaculatus), channel catfish (Ictalurus punctatus), and white bass (Morone chrysops). The rate of change in stomach capacity for a given change in fish length was greatest for spotted bass and channel catfish, which may indicate greater ontogenetic shifts in feeding strategies. Fish with larger stomach capacities should have more plastic diets because they are capable of consuming a wider range of prey sizes, particularly when they already have prey present in their stomach, compared to fish with smaller stomach capacities and similar feeding strategies.
\end{abstract}

\section{INTRODUCTION}

Energy acquisition, through the consumption of food, is a requirement for survival and growth of fishes. A basic ecological tenet is that a predator chooses the prey that it consumes to maximize net energetic gain. The energetic content of prey for most fishes increases with size whilst there is an associated increase in handling cost (Werner 1974, Kislalioglu and Gibson 1976, Hoyle and Keast 1986, Gill and Hart 1994) such that profitability of prey size can be defined as the energy consumed per unit handling time (Stephens and Krebs 1986). Handling time is a function of the predator gape in relation to the prey size, such that optimal prey size is directly related to fish gape size (Hambright 1991, Nilsson and Brönmark 2000, Husky and Turingan 2001). However, handling time is likely irrelevant for most piscivorous fishes that frequently select prey much smaller than the maximum size ingestible (Paszkowski and Tonn 1994, Nilsson and Brönmark 2000, Truemper and Lauer 2005). Rather, daily rations are more likely to be limited by rates of digestion or prey encounter (Breck 1993). Given that prey are patchily distributed, stomach capacity must play an important role in the consumption of food and, subsequently, predator-prey interactions in aquatic systems.

Growth of fishes is an important indicator of environmental conditions because energy is only physiologically available for tissue elaboration after standard metabolism, specific dynamic action, and non-resting activity energy needs are met (Brett and Groves 1979). Pope et al. (2001) demonstrated that mean stomach fullness, a diet index dependent on stomach capacity, was highly correlated with total caloric intake in largemouth bass (Micropterus salmoides) and was therefore an index with reasonable utility for energetic assessments of diet. However, a major limitation of the mean stomach fullness index is the paucity of information on stomach capacity of fishes. Therefore, we investigated the relationship between stomach capacity and total body length in bluegill (Lepomis macrochirus), spotted bass (Micropterus punctulatus), white crappie (Pomoxis annularis), black crappie (Pomoxis nigromaculatus), channel catfish (Ictalurus punctatus), and white bass (Morone chrysops).

${ }^{a}$ Present address: Missouri Department of Conservation, 2000 South Limit Avenue, Sedalia, Missouri 65301 USA; E-mail: Nate.Gosch@mdc.mo.gov 


\section{METHODS AND MATERIALS}

Several methods exist for determining stomach capacity of fish, each with their own unique advantages and biases (Hynes 1950, Kimball and Helm 1971, Burley and Vigg 1989, Phelps et al. 2007). Stomach capacity of fish was estimated indirectly by examining stomach contents of wild fishes, using the method outlined by Hellawell (1971 and 1972) and Knight and Margraf (1982). The premise of this method is that eating to fill the stomach is a common feeding strategy of many fishes (Brett 1971), and thus stomachs of individual fish at a given time range from empty to full. It is likely that when many similarly sized fish are captured throughout the days and seasons, at least one fish will have a full or nearly full stomach; this individual will be the one with the greatest volume of food in its stomach. The primary advantage of this method is that it logically incorporates fish behavior and other physiological factors along with stomach size, recognizing that fish do not feed until their stomach has nearly expanded to its physical maximum.

We collected bluegill and channel catfish in Blind Pony Lake and Macon Lake, Missouri, during 1998-2000 and spotted bass, white crappie, black crappie, and white bass in Pomme de Terre Lake and Stockton Lake, Missouri, during 1987-1991. Detailed descriptions of reservoir characteristics and sampling methodology are provided by Michaletz (1997 and 2006). Bluegill and channel catfish were collected monthly primarily by daytime electrofishing during May-October. Spotted bass were collected monthly by nighttime electrofishing, white crappie and black crappie were collected monthly by overnight trapnetting, and white bass were collected monthly by overnight gillnetting during April-October. Captured fishes were identified and measured (nearest $1 \mathrm{~mm}$; total length). Stomach contents were then removed using clear plexiglass tubes for all fishes and preserved, except stomach contents were removed via dissection for bluegill. Stomach contents were weighed to the nearest $0.01 \mathrm{~g}$ (bluegill and channel catfish) or measured volumetrically using volume displacement (spotted bass, white crappie, black crappie, and white bass). Weight of stomach contents for bluegill and channel catfish were converted to volume by assuming a specific density of one for all stomach contents because the majority of aquatic organisms have a specific density slightly greater than one (Lampert and Sommer 1997).

Species-specific assessments were completed. All fishes were divided into 10-mm length groups, except bluegill were divided into 5 -mm length groups. Length groups with fewer than 10 individuals were excluded from analysis. The maximum total volume of stomach contents found in each length group was plotted as a function of the midpoint of each length group. Three obvious outliers were removed (one each for bluegill, spotted bass, and channel catfish), and the next greatest stomach volume was used for the respective length group. Stomach capacity theoretically increases with length; thus, length groups whose maximum total volume of stomach contents was less than each of the two previous length groups were removed because it was likely that no fish captured within those length groups had full (or nearly full) stomachs. Remaining data points were used to develop the exponential regression equation, $\mathrm{V}=a \mathrm{~L}^{b}$, relating stomach capacity $(\mathrm{V}, \mathrm{mL})$ to total length $(\mathrm{L}, \mathrm{mm})$ (Knight and Margraf 1982). The PROC NLIN procedure of SAS software (SAS Institute, Cary, North Carolina) was used to obtain species-specific parameters and their associated standard errors for the regression models. Statistical significance was set at $\alpha=0.05$.

\section{RESULTS AND DISCUSSION}

We collected 719 bluegill, 663 channel catfish, 649 spotted bass, 2,563 white crappie, 788 black crappie, and 1,333 white bass. A significant exponential relationship existed between our indirect estimates of stomach capacity and total length for each species investigated (Fig. 1). Parameter estimates for $b$ for each investigated species 
ranged from 1.8 for bluegill to 5.0 for channel catfish.

Other species for which stomach capacity has been related to length include largemouth bass (M. salmoides) $(b=3.2$ [Pope et al. 2001]), walleye (Sander vitreus) $(b$ $=2.6$ [Knight and Margraf 1982]), and yellow perch (Perca flavescens) $(b=2.96$ [Phelps et al. 2007]), though no measure of variance was provided for the exponent $(b)$. The rate of change in stomach capacity for a given change in fish length is greater for species with
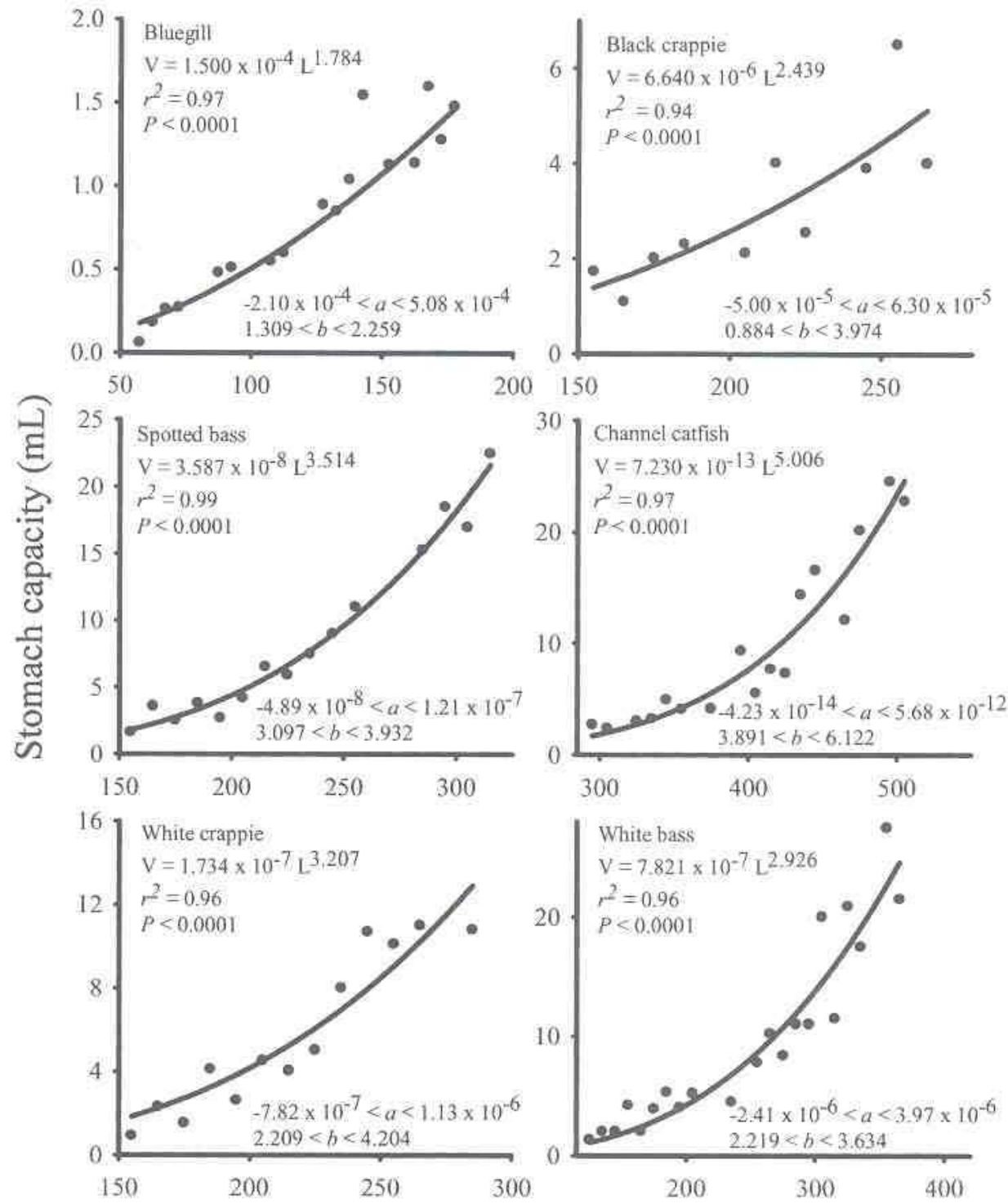

\section{Total length $(\mathrm{mm})$}

Figure 1. Relationships between maximum stomach capacity $(V)$ and total length (L) for six freshwater fishes collected from Missouri reservoirs. A point represents the maximum total volume of prey observed in an individual stomach plotted as the midpoint for each length group. Correlation coefficient and probability level for each exponential regression equation (capacity $=a \cdot$ Length $^{b}$ ) are provided along with upper and lower $95 \%$ confidence limits for parameter estimates $a$ and $b$. 
greater exponents. Thus, spotted bass and channel catfish experience the greatest rates of increase in stomach capacity with increasing length. These differences are likely a function of greater ontogenetic shifts in feeding strategies exhibited by these species. For example, piscivory becomes increasingly important for spotted bass (Smith and Page 1969) and channel catfish (Hubert 2000) as they grow, and thus larger stomachs relative to length might be beneficial because distributions of prey items become patchier as prey shifts from lower to higher trophic levels.

Stomach capacity is important for understanding predator-prey interactions in aquatic systems. When predators are not gape-limited, the next logical physical limitation on food consumption is how much the stomach can hold (i.e., stomach volume or capacity) (Truemper and Lauer 2005). Stomach capacity and size of prey relative to predator should provide important insight into ecological roles of fish. For example, large yellow perch were able to consume a constant biomass of fathead minnow (Pimephales promelas) regardless of available sizes of fathead minnow, whereas small yellow perch consumed less biomass when only large fathead minnow were available (Paszkowski and Tonn 1994). Therefore, fish with larger stomach capacities should have more plastic diets because they are capable of consuming a wider range of prey sizes, particularly when they already have prey present in their stomach, compared to fish with smaller stomach capacities and similar feeding strategies (Gill and Hart 1998).

\section{ACKNOWLEDGMENTS}

S.R. Chipps and Q. E. Phelps provided valuable comments on an earlier draft of this manuscript. The Nebraska Cooperative Fish and Wildlife Research Unit is jointly supported by a cooperative agreement among the U.S. Geological Survey, the Nebraska Game and Parks Commission, the University of Nebraska, the U.S. Fish and Wildlife Service, and the Wildlife Management Institute.

\section{LITERATURE CITED}

Breck, J.E. 1993. Foraging theory and piscivorous fish: are forage fish just big zooplankton? Transactions of the American Fisheries Society 122:902-911.

Brett, J.R. 1971. Satiation time, appetite, and maximum food intake of sockeye salmon (Oncorhynchus nerka). Journal of the Fisheries Research Board of Canada 28:409-415.

Brett, J.R. and T.D.D. Groves. 1979. Physiological energetics. Pages 279-352 In: Hoar, W.S., D.J. Randall, and J.R. Brett (eds.), Fish physiology, volume 8. Academic Press, New York, New York.

Burley, C.C. and S. Vigg. 1989. A method for direct measurement of the maximum volume of fish stomachs or digestive tracts. Journal of Fish Biology 34:707-714.

Gill, A.B. and P.J.B. Hart. 1994. Feeding behaviour and prey choice of the threespine stickleback: the interacting effects of prey size, fish size and stomach fullness. Animal Behaviour 47:921-932.

Gill, A.B. and P.J.B. Hart. 1998. Stomach capacity as a directing factor in prey size selection of three-spined stickleback. Journal of Fish Biology 53:897-900.

Hambright, K.D. 1991. Experimental analysis of prey selection by largemouth bass: role of predator mouth width and prey body depth. Transactions of the American Fisheries Society 120:500-508.

Hellawell, J.M. 1971. The autoecology of chub, Squalis sephalus (L.) of the River Lugg and Afon Llynfi. III. Diet and feeding habits. Freshwater Biology 1:369-387.

Hellawell, J.M. 1972. The growth, reproduction and food of the roach, Rutilus rutilus (L.) of the River Lugg, Herefordshire. Journal of Fish Biology 4:469-486.

Hoyle, J.A. and A. Keast. 1986. The effect of prey morphology and size on handling time in a piscivore the largemouth bass, Micropterus salmoides. Canadian Journal of Zoology 65:1972-1977. 
Hubert, W.A. 2000. Biology and management of channel catfish. Pages 3-22 In: Irwin, E.R., W.A. Hubert, C.F. Rabeni, H.L. Schramm, Jr., and T. Coon (eds.), Catfish 2000: Proceedings of the International Ictalurid Symposium. American Fisheries Society, Bethesda, Maryland.

Husky, S.H. and R.G. Turingan. 2001. Variation in prey-resource utilization and oral jaw gape between two populations of largemouth bass, Micropterus salmoides. Environmental Biology of Fishes 61:185-194.

Hynes, H.B.N. 1950. The food of freshwater sticklebacks (Gasterosteus aculeatus and Pygosteus pungitius) with a review of methods used in studies of the food of fishes. Journal of Animal Ecology 19:35-58.

Kimball, D.C. and W.T. Helm. 1971. A method of estimating fish stomach capacity. Transactions of the American Fisheries Society 100:572-575.

Kislalioglu, M. and R.N. Gibson. 1976. Prey 'handling time' and its importance in food selection by the fifteen-spined stickleback, Spinachia spinachia. Journal of Experimental Marine Biology and Ecology 25:151-158.

Knight, R.L. and F.J. Margraf. 1982. Estimating stomach fullness in fishes. North American Journal of Fisheries Management 2:413-414.

Lampert, W. and U. Sommer. 1997. Limnoecology: the ecology of lakes and streams. Oxford University Press, New York.

Michaletz, P.H. 1997. Influence of abundance and size of age-0 gizzard shad on predator diets, diet overlap, and growth. Transactions of the American Fisheries Society 126:101-111.

Michaletz, P.H. 2006. Prey resource use by bluegill and channel catfish in small impoundments. Fisheries Management and Ecology 13:347-354.

Nilsson, P.A and C. Brönmark. 2000. Prey vulnerability to a gape-size limited predator: behavioural and morphological impacts on northern pike piscivory. Oikos 88:539546.

Paszkowski, C.A. and W.M. Tonn. 1994. Effects of prey size, abundance, and population structure on piscivory by yellow perch. Transactions of the American Fisheries Society $123: 855-865$.

Phelps, Q.E., K.A. Powell, S.R. Chipps, and D.W. Willis. 2007. A method for determining stomach fullness for planktivorous fishes. North American Journal of Fisheries Management 27:932-935.

Pope, K.L., M.L. Brown, W.G. Duffy, and P.H. Michaletz. 2001. A caloric-based evaluation of diet indices for largemouth bass. Environmental Biology of Fishes 61:329-339.

Smith, P.W. and L.M. Page. 1969. The food of spotted bass in streams of the Wabash River drainage. Transactions of the American Fisheries Society 98:647-651.

Stephens, D.W. and J.R. Krebs. 1986. Foraging theory. Princeton University Press, Princeton, New Jersey.

Truemper, H.A. and T.E. Lauer. 2005. Gape limitation and piscine prey size-selection by yellow perch in the extreme southern area of Lake Michigan, with emphasis on two exotic prey items. Journal of Fish Biology 66:135-149.

Werner, E.E. 1974. The fish size, prey size, handling time relation in several sunfishes and some implications. Journal of the Fisheries Research Board of Canada 31:1531-1536. 